\section{MARIJA HADŽI-NIKOLOVA ${ }^{1}$ DEJAN MIRAKOVSKI ${ }^{2}$ NIKOLINKA DONEVA ${ }^{3}$ NATAŠA BAKRESKA ${ }^{4}$ \\ 1,2,3 Goce Delcev University of Stip, Faculty of Natural and Technical Sciences \\ ${ }^{4}$ TITAN Usje Cement Plant Skopje, \\ ${ }^{I}$ marija.hadzi-nikolova@ugd.edu.mk ${ }^{2}$ dejan.mirakovski@ugd.edu.mk ${ }^{3}$ nikolinka.doneva.ugd.edu.mk 4natasak@usje.com.mk}

\title{
ENVIRONMENTAL AND OCCUPATIONAL NOISE MANAGEMENT PROCESS IN CEMENT INDUSTRY
}

Abstract: The main environmental issues associated with cement production are the consumption of raw materials, energy use and emissions in the air. Noise emissions occur throughout the whole cement manufacturing process - from preparing and processing raw materials, from the clinker burning and cement production process, from material storage as well as from the dispatch and shipping of the final products. The heavy machinery and large fans used in the cement manufacturing process can give rise to noise emissions. Cement Plants are required to comply with standards for reduction in line with national legislation, and to conduct measurements and perform noise surveys.

Having this in mind, A TITAN Group Usje Cement Plant in Skopje, following their strong commitment to high environmental performance and Corporate Social Responsibility and Sustainable Development Policy in 2013-2014 have engaged an AMBICON Lab (Faculty of Natural and Technical Sciences) from Stip, to conduct a Noise Control Study in order to identify noise sources within cement plant and marl quarry, determine their impacts on nearby residents and develop noise control/protection strategies. During the past three years, the Usje Cement plant has implemented most of the noise control measures proposed in this Study. Also, a follow-up study during 2016-2017 was conducted in order to assess the effectiveness of measures taken. This paper presents the outcomes of noise reduction measures taken.

Keywords: noise, cement industry, process management, measures, environment.

\section{INTRODUCTION}

Noise, one of the most widespread occupational hazardous agents, contributes to $16 \%$ mortality and morbidity due to the global burden of occupational diseases and injuries [1]. Also, the World Health Organization [WHO] report, [22] clearly indicates that noise-induced hearing loss (NIHL) is the most prevalent irreversible occupational hazard. Exposure to excessive noise is one of the major causes of hearing disorders. It has been estimated that about 500 million people worldwide might be at risk of developing noiseinduced hearing loss [18]. Prolonged exposure to noise at high intensity is associated with damage to the sensory hearing cells of the inner ear and development of permanent hearing threshold shift, as well as poor speech in noise intelligibility [10].

Noise is considered as a very important part of environmental pollution, with a major negative impact on life quality in urban areas. Transport and industry are by far most frequent noise sources within urban areas [4]. Based on the World Health Organization (WHO) data, noise pollution was the third most dangerous environmental pollution, after exhaust emissions pollution and water pollution [5, 6]. In addition, a large number of research and compliance studies in recent decades, have indicated noise pollution as significant environmental issue, which poses a real threat to people's health and life quality [7].

The cement plant is considered one of the noisiest working environments. Several studies in many countries have reported high noise exposure in different industries, however, few have focused on cement factories $[2,3,8,9,12]$. Although the noise pollution issues steadily grow, especially in developing countries, these problems are rarely addressed in a systematic manner and are most often overlooked because their effects are not sudden or striking [15]. In addition, noise pollution has been largely ignored in terms of its impact on health and wellbeing [14, 16, 21].

A TITAN Group Usje Cement Plant in Skopje, following their strong commitment to high environmental performance and Corporate Social Responsibility and Sustainable Development Policy in 2013/14 have engaged an AMBICON- FTNS Lab from Stip, to conduct a Noise Control Study in order to identify noise sources within cement plant and marl quarry, determine their impacts on nearby residents and develop noise control/protection strategies. Based on noise level measurements at noise sources, a Noise Dispersion Model for cement plant and marl quarry was developed. Working closely with plant engineers, a 
wide variety of control measures were modelled and based on the effects obtained from three different scenarios. Realistic, High and Ultimate protection level were developed.

During the past three years, the Usje Cement plant has completed most of the noise control measures proposed in a realistic scenario. Also, a follow-up study was conducted in order to assess the effectiveness of measures taken (Usje Cement Plant and AMBICON Lab, 2016/2017). This paper presents the outcomes of noise reduction measures taken.

\section{METHODS}

Noise Control Study in 2013, [19] has a phased approach starting from noise sources identification and profiling (measurements), noise modeling (DGM development, source modeling, and maps generation), model verification and ending with control measures modeling, maps generation and scenarios development.

As the first step in study development, a 15 minutes' noise levels measurement in one-third octave band were performed and source-specific noise profiles were created for all noise sources identified within the plant and the quarry. Noise measurements were performed in one-third frequency octave band according to ISO 1996 2:2010 Acoustics - Description, measurement, and assessment of environmental noise - Part 2: Determination of environmental noise levels, using a Sound Level Meter type CR: 171C, an instrument Class 1 according to IEC 61762 .

Measurements have been performed at 1,5 m height nearby noise sources and on the most exposed facade of buildings at a 3,5 $\mathrm{m}$ distance from the buildings' walls and other reflective surfaces [13]. Frequency analysis provides additional information about the noise source as well as about the prevalence of certain frequencies, whether they are in humans' hearing range.

Main noise sources within the marl quarry, as expected, involve heavy mining machinery like bulldozers, excavators, truck-tippers, primary crusher and marl transport conveyors [19, 20]. Noise sources within cement plant include sources like blowers, mills, fans, filters and compressed air generators [17].

Noise levels for main sources within quarry range were between minimal $64.5 \mathrm{~dB}$ for trucks and $98.6 \mathrm{~dB}$ for bulldozers, while in the plant the noise levels were between $82.5 \mathrm{~dB}$ for filters up to 100,2 for blowers (Table 1).

Noise level data (source-specific profiles) were embedded within a digital ground model (DGM) for the plant, quarry, and their closest neighbourhood, using the one of the most advanced Noise and Air Pollution Modelling Software's, SoundPLAN 7.2, produced by Braunstein + Berndt $\mathrm{GmbH} /$ SoundPLAN International LLC. The software uses tools for DGM development, noise source approximation, and contour maps calculation [11].
Table 1. Measured Noise Level close to the main noise sources

\begin{tabular}{c|c}
\hline Noise Source & $\begin{array}{c}\text { Measured Leq,15min } \\
{[\mathbf{d B}(\mathbf{A})]}\end{array}$ \\
\hline Bulldozers & $95,8-98,6$ \\
\hline Excavators & $78,8-81,2$ \\
\hline Truck-Tippers & $64,5-69,7$ \\
\hline Primary Crusher & $83,4-86,3$ \\
\hline Transport Conveyor & $77,3-78,6$ \\
\hline Blowers & $98,3-100,2$ \\
\hline Cement and Raw mill & $95,7-99,3$ \\
\hline Fan & $86,2-88,3$ \\
\hline Filter & $82,5-87,3$ \\
\hline Compressor stations & $83,8-86,7$ \\
\hline
\end{tabular}

Using the same software tools, noise dispersion (contours) maps for the area of interest were developed (Fig. 1 and 2) and noise impacts assessed. Having in mind specific plant operation regime (daytime work in the quarry and no third shift in the plant), separate noise dispersion maps (2D and 3D) have been developed for the day and the night time.

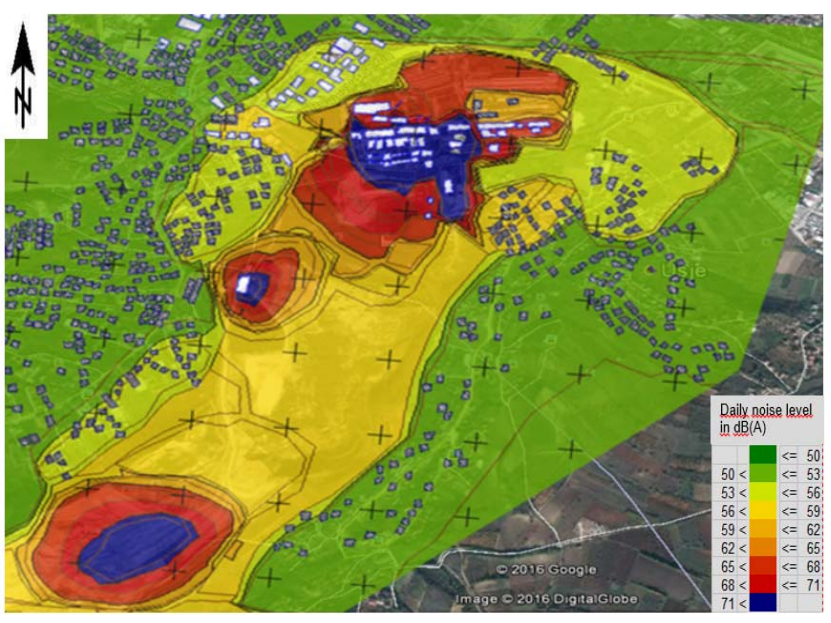

Figure 1. Day time noise dispersion map (2D) for an area of interest [19]

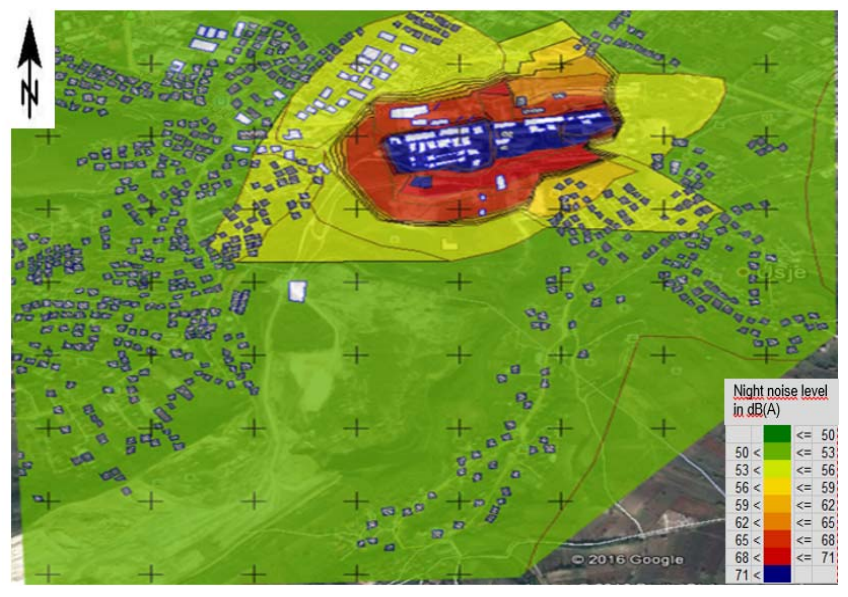

Figure 2. Night-time noise dispersion map for an area of interest [19] 
In order to verify the Noise Dispersion Model (NDM) developed, broadband measurements were taken at 20 measurement points within the plant and quarry area, and at 10 measurement points close to residents in their neighborhood.

Measured equivalent noise levels - $\mathrm{L}_{\mathrm{eq}}$ (Equivalent noise level) were compared against modeled equivalent noise (Tables 2 and 3 ). The data clearly indicate excellent compliance between modeled and measured data. Small deviations that occur at individual measurement points are a result of additional noise sources (mostly nearby roads), which were taken into account through noise dispersion model adjustment procedure.

Table 2. The comparison of measured and modeled equivalent noise levels (Leq) within the plant area

\begin{tabular}{c|c|c}
\hline $\begin{array}{c}\text { Measurement } \\
\text { point }\end{array}$ & $\begin{array}{c}\text { Measured } \\
\mathrm{L}_{\text {eq, } 15 \min \mathrm{dB}(\mathrm{A}),} \\
2016\end{array}$ & $\begin{array}{c}\text { Leq,15min } \mathrm{dB}(\mathrm{A}) \\
\text { according to the } \\
\text { model }\end{array}$ \\
\hline 1 & 74,2 & $73-77$ \\
\hline 2 & 73,5 & $73-77$ \\
\hline 3 & 60,5 & $65-69$ \\
\hline 4 & 58,5 & $<61$ \\
\hline 5 & 69,9 & $69-73$ \\
\hline 6 & 66,5 & $65-69$ \\
\hline 7 & 60,2 & $<61$ \\
\hline 8 & 76,4 & $73-77$ \\
\hline 9 & 72,3 & $73-77$ \\
\hline 10 & 84,7 & $>77$ \\
\hline 11 & 79,3 & $>77$ \\
\hline 12 & 78,7 & $>77$ \\
\hline 13 & 68,3 & $65-69$ \\
\hline 14 & 71,1 & $69-73$ \\
\hline 15 & 70,1 & $69-73$ \\
\hline 16 & 64,5 & $61-65$ \\
\hline 17 & 64,6 & $65-69$ \\
\hline 18 & 71,6 & $69-73$ \\
\hline 19 & 75,3 & $73-77$ \\
\hline 20 & 62,9 & $65-69$ \\
\hline
\end{tabular}

Table 3. The comparison of measured and modeled equivalent noise levels (Leq) in plant and quarry neighborhood

\begin{tabular}{c|c|c}
\hline $\begin{array}{c}\text { Measurement } \\
\text { point }\end{array}$ & $\begin{array}{c}\text { Measured } \\
\mathrm{L}_{\text {eq,24h }}[\mathrm{dB}(\mathrm{A})], \\
2016\end{array}$ & $\begin{array}{c}\mathrm{L}_{\mathrm{eq}}[\mathrm{dB}(\mathrm{A})] \\
\text { according } \\
\text { model }\end{array}$ \\
\hline 1 & 49,7 & $<50$ \\
\hline 2 & 50,1 & $53-56$ \\
\hline 3 & 50,8 & $53-56$ \\
\hline 4 & 50,9 & $53-56$ \\
\hline 5 & 51,6 & $53-56$ \\
\hline 6 & 52,5 & $56-59$ \\
\hline 7 & 56,3 & $56-59$ \\
\hline 8 & 52,0 & $53-56$ \\
\hline 9 & 45,7 & $<50$ \\
\hline 10 & 46,5 & $<50$ \\
\hline
\end{tabular}

In the final phase, TITAN-Usje and AMBICON joint teams developed a Noise Reduction Plan (NRP), which described protection measures and set up the priorities. Based on the anticipated measures reduction levels, three stages (realistic, high and ultimate) were additionally modeled using the same SoundPLAN 7.2 platform.

\section{RESULTS AND DISCUSSION}

Following the NRP [19], in the last three years, TITAN Usje Cement Plant has taken most of the noise reduction and control measures as recommended in a realistic scenario (Scenario 1). Most of the measures were taken at noise sources within the plant and in vicinity of the marl quarry, and include: closing blowers in acoustic enclosure (Fig.3), a purchase of new fans with lower noise levels (Fig.4), setting silencers on existing fans and exhaust openings, fencing noise sources (primary crusher, exhaust fan for kiln 3) with acoustic panels and setting acoustic louvers on compressed air station ventilation openings.

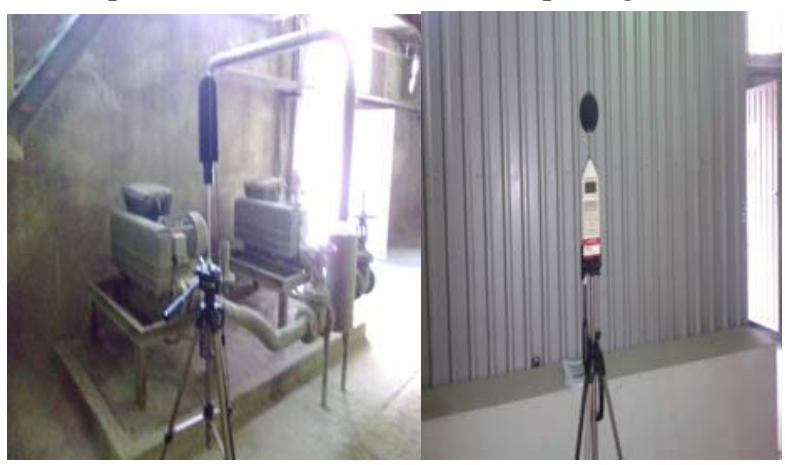

Figure 3. Closing blowers in an acoustic enclosure

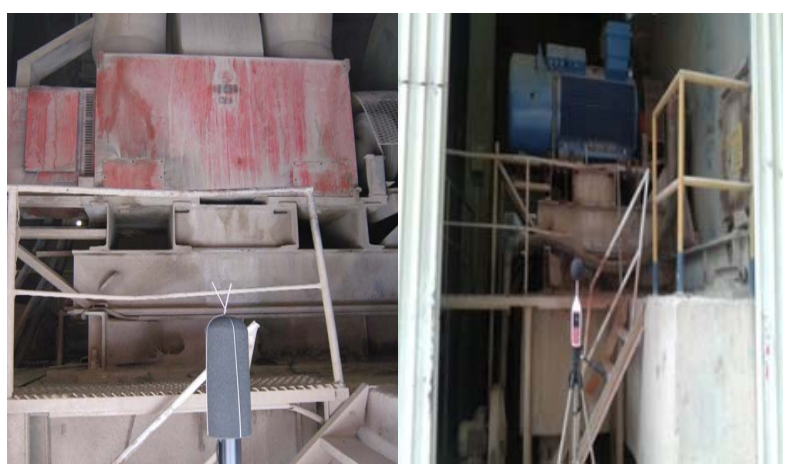

Figure 4. New Exhaust fan for rotary kiln 4

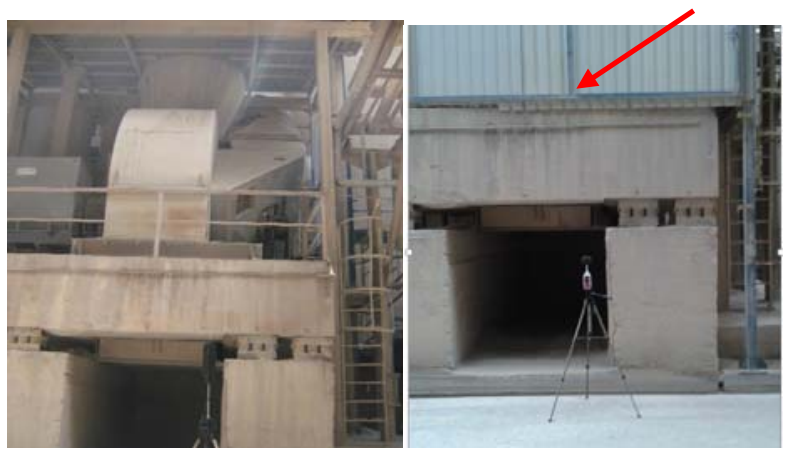

Figure 5. Fencing of exhaust fan for kiln 3 
As a result of a silencer that was installed at a fan of filter for kiln 3, the noise level is reduced from $86,5 \mathrm{~dB}$ (A) in 2013 , to $72,5 \mathrm{~dB}(\mathrm{~A})$ in 2016.

Table 4. Measured noise level at fans before and after noise reduction measures taken

\begin{tabular}{|c|c|c|}
\hline Fan & $\begin{array}{c}\text { Measured } \\
\mathrm{L}_{\text {eq }, 15 \min ,} 2013 \\
{[\mathrm{~dB}(\mathrm{~A})]} \\
\end{array}$ & $\begin{array}{c}\text { Measured } \\
\mathrm{L}_{\text {eq }, 15 \min , 2016} \\
{[\mathrm{~dB}(\mathrm{~A})]} \\
\end{array}$ \\
\hline Exhaust fan for kiln 4 & 93,5 & 86,9 \\
\hline $\begin{array}{l}\text { Fan from an auxiliary } \\
\text { filter in solid fuel } \\
\text { preparation facility }\end{array}$ & 92,4 & 72,2 \\
\hline $\begin{array}{l}\text { Fan from mill filter in } \\
\text { solid fuel preparation } \\
\text { facility }\end{array}$ & 83,6 & 62,1 \\
\hline Exhaust fan for kiln 3 & 87,8 & 86,5 \\
\hline Fan of filter for kiln 3 & 86,5 & 72,5 \\
\hline
\end{tabular}

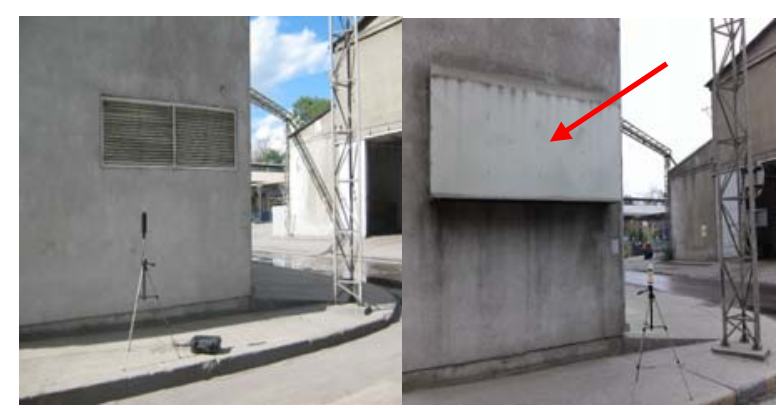

Figure 8. Cement mills `compressor station

Table 5. Measured noise level in front of the compressor station before and after noise reduction measures taken

\begin{tabular}{c|c|c}
\hline Compressor station & $\begin{array}{c}\text { Measured } \\
\mathrm{L}_{\mathrm{eq}, 15 \min , 2013} \\
{[\mathrm{~dB}(\mathrm{~A})]}\end{array}$ & $\begin{array}{c}\text { Measured } \\
\mathrm{L}_{\mathrm{eq}, 15 \min , 2016} \\
{[\mathrm{~dB}(\mathrm{~A})]}\end{array}$ \\
\hline Packing Plant 2 & 78,4 & 69,9 \\
\hline Cement mills & 73,8 & 72,3 \\
\hline $\begin{array}{c}\text { Solid fuel } \\
\text { preparation facility }\end{array}$ & 80,1 & 68,3 \\
\hline
\end{tabular}

In order to assess the effectiveness after completing the NRP according to the realistic scenario, a follow-up study was initiated during 2016/17, using the same approach as above. New source profiles were generated (measured) for all sources amended according to the plan. The new noise dispersion model, taking into account reduction measures, was developed and verified. Noise contour maps clearly indicate significant noise reduction levels in the zones where the measures were taken. Significant reduction of day and especially night noise levels is evident at solid fuel preparation facility, packing plant No.2 and west side of pre-heater cyclone tower ${ }^{21}$ (yellow marked areas at Fig.9 and Fig.10).

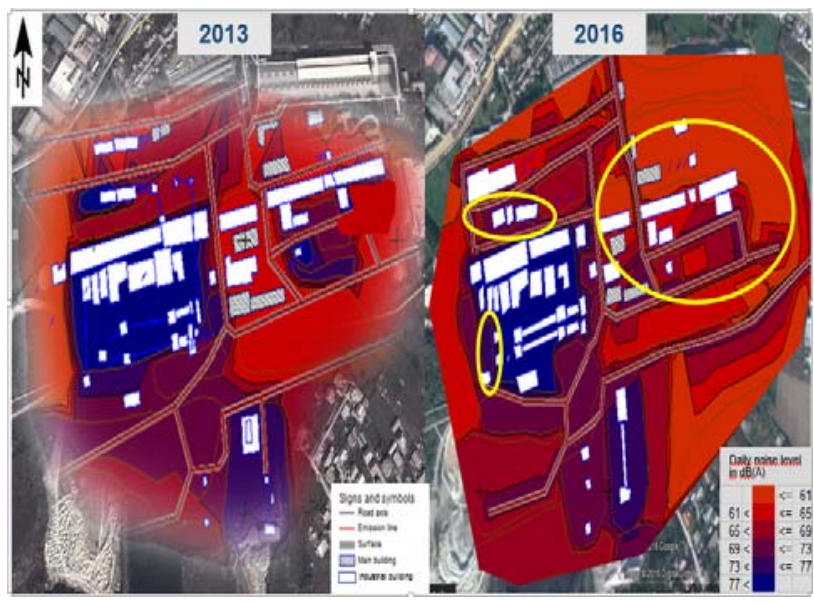

Figure 9. Comparison of day time noise contour maps for plant area (2013 vs 2016) 


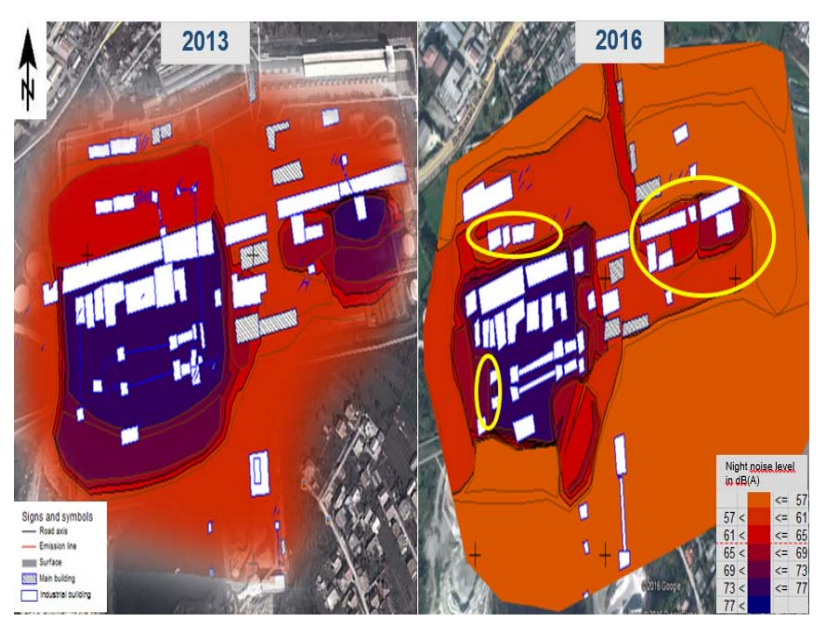

Figure 10. Comparison of day time noise contour maps for plant area (2013 vs 2016)

The results presented here proved that the approach taken is a rational and effective pathway for reducing noise pollution impacts around the industrial plants, even when they are located near the residential areas. The models show good compliance with measured results and can be used with confidence.

\section{CONCLUSION}

Modern industry is facing ever-increasing challenges to reduce their environmental footprints and satisfy regulations, especially in case of distinguishable industries that draw public attention. We strongly believe that the example of a proactive approach presented in this paper is to only way to address possible environmental issues in a timely and efficient manner. TITAN Usje in Skopje had initiated Noise Control Study well before the complaints or regulatory breach occurred.

Phased study approach started with noise sources identification and profiling (measurements), noise modeling (DGM development, source modeling, and maps generation), model verification, and ended with control measures modeling, maps generation and scenarios development, proved as a rational and effective pathway for reducing noise pollution impacts around industrial plants. The presented models are in compliance with measured results and, therefore, can be used with confidence. This approach allows proper noise control measures planning and execution, and the possibility to keep noise levels within the regulation limits.

\section{REFERENCES}

[1] Alberti P., Noise-induced hearing loss - A global problem, [in:] Advances in noise research, Vol 1, Protection against noise, Luxon L., Prasher D., [Eds], pp.7-15, Whurr Publisher Ltd, London, 1998.

[2] Ahmadi Orkomi A, Tavakoli B, Noorpoor A., Noise pollution analysis in Tehran cement plant, JOHE, Winter-spring; 2 (1-2), 2013.

[3] Asdrubali F, Baldinelli G. Acoustic impact evaluation and mitigation of cement production plants. Presented at the 32nd international congress and exposition on noise control engineering jeju international convention center, Seogwipo, Korea, August 25-28, pp. 25-28, 2003.

[4] Baubonytė I., Gražulevičienė V., Road Traffic Flow and Environmental Noise in Kaunas City, Environmental Research, Engineering and Management, No.1(39), pp. 49-54, ISSN 1392 - 1649, 2007.

[5] Babisch W., Cardiovascular effects of noise, In: Nriagu JO, Encyclopedia of Environmental Health, Vol. 1. Burlington: Elsevier; pp.532-42, 2011.

[6] Babisch W., Cardiovascular effects of noise, Noise \& Health, 13:201-4, 2011.

[7] Button D.C., Behm D.G., Holmes M., Mackinnon S.N., Noise and muscle contraction affecting vigilance task performance. Occupational Ergonomics 4, 751-756, 2004.

[8] Canfeng Z, Shujie Y, Dong L, Comprehensive control of the noise occupational hazard in cement plant, Procedia Engineering; (43):186-90, 2012.

[9] Ghotbi Ravandi MR, Nadri F, Khanjani N, Ahmadian M, Occupational noise exposure among the workers of Kerman Cement Plant, JOHE, Spring 2012; 1 (1), 2009.

[10] Hadzi-Nikolova M., Mirakovski D., Zdravkovska M., Angelovska B., Doneva N., Noise Exposure of School Teachers - Exposure Levels and Health Effects. In: Archives of Acoustics. Polish Academy of Sciences, Warszawa, pp. 259-264, 2013.

[11] Hadzi-Nikolova M., Mirakovski D., Ristova E., Ceravolo LJ.S, Modelling and Mapping of Urban Noise Pollution with SoundPLAN Software. International Journal for Science, Technics and Innovations for the Industry MTM (Machines, Technologies, Materials), VI (5/2012). pp. 38-42. ISSN 1313-0226, 2012.

[12] Hernandez-Gaytan SI, Santos-Burgoa C, Becker-Meyer JP, Macias-Carrillo C, Lopez-Cervantes M. Prevalence of hearing loss and correlated factors in cement plant. Salud Publica Mex; 42(2):106-112, 2000.

[13] ISO 1996 2:2010 Acoustics -- Description, measurement and assessment of environmental noise - Part 2: Determination of environmental noise levels.

[14] Kepeski A., Mirakovski D., Hadzi-Nikolova M., Doneva N., Personal noise exposure on mining workers, Natural Resources and Technologies, 10 (10). pp. 49-61. ISSN 185-6966, 2016.

[15] Maleki K., Hosseini S.M., Nasiri P., The Effect of Pure and Mixed plantations of Robinia Pseudoacasia and Pinus Eldarica on Traffic Noise Decrease, International Journal of Environmental Science, 1-2, 2010.

[16] Mathews R., The Effect of Community Noise on Health and Well-being, Master dissertation, Auckland University of Technology, New Zealand, 2009.

[17] Mirakovski D., Hadzi-Nikolova M., Ristovic I., Despodov Z., Panov Z. (2011). Modelling of noise impact assessment on the aggregate surface mines. In: Integrated International Symposium - ISTI, ORRE, IRSE, 11-15 September 2011, Zlatibor, Serbia, 2011.

[18] Nelson DI, Nelson RY, Concha-Barrientos M, Fingerhut M., The global burden of occupational noise-induced hearing loss, Am J Ind Med, 48, 446-458, 2005.

[19] Noise Control Study in the vicinity of Usje Cement Plant, Investigation of main noise sources and Plan of activities (proposals and prioritization), Faculty of Natural and Technical Sciences, Goce Delcev University, Stip, 2013. 
[20] Study for determining the effectiveness of Noise Reduction Measures taken in Titan Usje Cement Plant, Faculty of Natural and Technical Sciences, Goce Delcev University, Stip, 2017.

[21] Sharma O, Mohanan V, Singh M. Noise emission levels in coal industry. Applied Acoustics 1998; 54(1):1-7, 1998.

[22] WHO, Guidelines for Community Noise, pp.21, 1999.

\section{ACKNOWLEDGEMENTS}

This paper is part of a Study that was supported by TITAN Usje Cement Plant in Skopje, with the participation of Environmental Department management and personnel. The authors are grateful for useful advice and sincere collaboration during the Noise Control Study preparation.

\section{BIOGRAPHY of the first author}

Marija Hadzi-Nikolova was born in Stip, Macedonia, in 1972. She received a Ph.D. degree in Environmental protection from the Goce Delcev University of Stip, Faculty of Natural and Technical Sciences. Her main areas of research include:

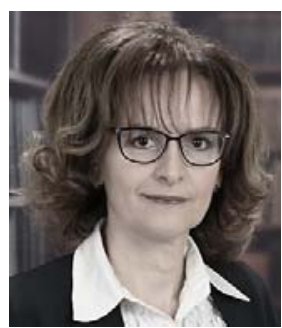
occupational health and safety, noise modeling and mapping, environmental protection, etc.

She is currently working as an Associate Professor on Environmental Department, Faculty of Natural and Technical Sciences, Goce Delcev University in Stip.

\title{
UPRAVLJANJE ZAŠTITOM ŽIVOTNE SREDINE I ZAŠTITOM NA RADU U INDUSTRIJI CEMENTA
}

\author{
Marija Hadži-Nikolova, Dejan Mirakovski, Nikolinka Doneva. Nataša Bakreska
}

Rezime: Najčešći problemi zaštite životne sredine u proizvodnji cementa su potrošnja sirovina $i$ korišćenje energije, kao $i$ emisije u vazduh. Emisija buke nastaje tokom celog procesa proizvodnje cementa, počevši od pripreme $i$ prerade sirovina, sagorevanja klinkera i proizvodnje cementa, skladištenja materijala, pa sve do isporuke $i$ transporta finalnih proizvoda. Teška mehanizacija $i$ veliki ventilatori koji se koriste u procesu proizvodnje cementa mogu dovesti do velikih emisija buke. Fabrike cementa su u obavezi da poštuju standarde za smanjenje nivoa buke u skladu sa nacionalnim zakonodavstvom, kao i da redovno sprovode merenja i ispitivanja nivoa buke. Imajući to u vidu, Cementara Usje, TITAN Group u Skoplju, zbog izražene posvećenosti visokim ekološkim performansama i korporativnoj društvenoj odgovornosti, kao i politici održivog razvoja je tokom 2013/14. godine angažovala laboratoriju AMBICON (sa Fakulteta za prirodne I tehničke nauke) iz Štipa, da sprovede studiju o kontroli buke u cilju identifikacije izvora buke u cementari i rudniku laporca, utvrdi njihov uticaj na okolno stanovništvo i izradi strategiju za kontrolu/zaštitu od buke. Tokom poslednje tri godine, cementara Usje je sprovela većinu mera za kontrolu buke predloženih u ovoj studiji, kao i dodatnu studiju tokom 2016/17 godine u cilju procene efikasnosti preduzetih mera. U radu su predstavljeni rezultati preduzetih mera za smanjenje nivoa buke.

Ključne reči: buka, industrija cementa, procesni menadžment, mere, životna sredina. 